\title{
Determinants Of, And Barriers To, Market Orientation And The Relationship With Business Performance Among SMEs
}

Job Dubihlela, Nelson Mandela Metropolitan University, South Africa Manilall Roy Dhurup, Vaal University of Technology, South Africa

\begin{abstract}
Expansion, diversification, greater choice, market share, profits and increased competition are the "overarching forces" that drive organisations to embrace marketing concepts such as market orientation. Various researchers assert that market orientation is a vital marketing concept for the performance of businesses and for small and medium enterprises (SMEs) there are no exceptions. The study examines the relationship of the determinants and barriers to market orientation and the influence of market orientation on business performance among SMEs in a developing country. This cross-sectional study made of a quantitative survey design. The target population comprised 273 owners/managers of SMEs in the Vaal Triangle, South Africa. The results revealed that the determinants of market orientation exhibited a strong influence in market orientation. Market orientation in turn showed strong positive relationship with business performance. Barriers to market orientation showed strong negative relationship with market orientation. The study identified the constructs that foster or discourage market orientation, and the contribution that market orientation can have on business performance for SMEs. SMEs owner/mangers are encouraged to consider the market orientation constructs that positively influences the performance of their businesses.
\end{abstract}

Keywords: Market Orientation; Determinants; Barriers; Business Performance

\section{INTRODUCTION}

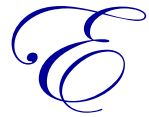

xpansion, diversification, greater choice, market share, profits and increased competition are the "overarching forces" that drive organisations to embrace marketing concepts such as market orientation. Market orientation has become one of the major research streams developed during the last few decades (Sin et al., 2003), and continues to captivate researchers, academicians, owners and managers in marketing (Guo, 2003). Market orientation has been recognised as a strategic tool for achieving operational efficiency and improved positive organisational performance. Notwithstanding such affirmations, the frameworks developed by Jaworski and Kohli (1996) and Narver and Slater (1990) provide an interesting avenue for gaining a comprehensive understanding of the market orientation dimensions, barriers and their influence in business performance.

The SME sector is widely regarded as the driving force in economic growth and job creation in both developed and developing countries (White \& Simas, 2008). In South Africa, the total economic output of small and medium enterprises (SMEs) is nearly $40 \%$ of gross domestic product (GDP), and this sector employs in excess of 60 per cent of the total labour force (Statistics South Africa, 2005). As medium-term employment trends in the formal sector are stagnant at the moment, the level of unemployment in the local economy can be reduced meaningfully in the near future by the successful promotion of SME output (Republic of South Africa, 2004). The SME sector will be the focus of this study in relation to the way in which it adopts and implements market orientation strategies. Although the classification of enterprises is normally based on size, turnover and number of employees, the definition of an SME differs: in the literature, no fixed definition exists (Edigheji, 2010). For the purposes of this 
research the description of SMEs as applied in terms of the South African National Small Business Act, No102 of 1996 will be used where SME is defined as "a separate and distinct business entity, including cooperative enterprises, non-governmental organisations; managed by one owner or more people; which cannot form part of a group of companies; has been established solely for promoting the interests of small and medium enterprises" (Ntsika, 2009:3).

The study examines the relationship of the determinants and barriers to market orientation and the relationship with business performance among SMEs in a developing country.

\section{Market Orientation}

Kohli and Jaworski (1990:123) offered a formal operational definition of market orientation. According to them, "market orientation is an organisation-wide generation of market intelligence through decision support systems, marketing information systems, marketing research efforts, dissemination of the intelligence across company departments, and organisation-wide responsiveness to the changes taking place in the environment." The definition means that the concept focuses on generation of coordinated business intelligence, and dissemination of and responsiveness to market information for efficient and effective decision-making. Dursun-Kilic (2006) views effective dissemination of market intelligence as a vital act since it provides a shared basis for collaborative efforts by different departments. Various other scholars have either adopted or extended the annotated formal operational definition. According to Ruekert (1992:229), market orientation is "a concept focused on efficient and effective decision-making through coordinated business operations involving market intelligence generation, marketinformation dissemination and organisational responsiveness". Maydeu-Olivares and Lado (2003:286) also added value to the formal operational definition when they defined market orientation as "the integration and dissemination of market intelligence across departments and the coordinated design and execution of the firm's strategic response to market opportunities". Complementing the works of Kohli and Jaworski (1990), Narver and Slater (1990:21) defined market orientation as "customer orientation, competitor orientation, and their inter-functional co-ordination, which involves intelligence, dissemination, and managerial action". Later, Narver et al. (1998:241) then extended this definition, suggesting that market orientation is "an organisational culture that most effectively and efficiently creates the necessary behaviours for the creation of superior value". The stress on creating the necessary behaviour indicates the importance of considering the conditions necessary for the implementation of the marketing concept.

\section{Barriers to Market Orientation}

Although market orientation is critical for its influence on business performance, there are several barriers that impede its implementation and usage. Generally, barriers to market orientation have received limited analysis (Oczkowski \& Farrell, 1998). The available literature does identify barriers to market orientation development which are complex, interrelated and numerous. It is worth noting that most studies on barriers to market orientation share the common theme of behaviour (Piercy, 1995). The first group includes the studies that are focused on people, emphasising on the control of employee behaviour; the second group comprises the structure-focused studies, which investigate and emphasise the manifestations of behaviour in the form of structures, systems and processes (Hill \& Wright, 2001). The diversity of academic opinion regarding the components of market orientation is matched by the variety of barriers to market orientation (Garver \& Gagnon, 2002). Consequently, the review of the literature on the barriers to market orientation is limited to studies that have identified market orientation components. The barriers to market orientation can be divided into three broad areas. The first area is the external environment, the second area is operational environment and the third area is the internal environment. These are explained in detail in the following sections.

External environment barriers result from three elements: the state, the economy and technological changes (Kotler \& Armstrong, 2011). Elements of the external environment are uncontrollable, difficult to deal with and may not be eliminated by the organisation in itself (Hill \& Wright, 2001). The factors that constitute the external environment are competition, market turbulence, technological changes and the general economic conditions (Blewett, 1999). 
While a myriad of factors (including the weather and the business cycle) affect industry profitability in the short run, industry structure, manifested in the competitive forces, prompts industry profitability in the medium and long run. It is clear that the level of competitiveness of the industry can deter operations and hence be a barrier to market orientation.

Jaworski and Kohli (1996) define market turbulence as the "rate of change in the composition of customers and their preferences." Levitt (1980) augments this by arguing that the organisation does not have to develop a market orientation if it operates in a familiar, stable and predictable market. However, a problem arises when markets do not remain stable or predictable all the time and thus an organisation should make more effort to cope with this instability and unpredictability (e.g. the organisation should become market oriented), "while those who fail to do, simply die" (Day, 2000:27). Jaworski and Kohli (2000) assert that organisations that operate in the more turbulent markets are likely to have to modify their products and services continually in order to satisfactorily cater to customers' changing preferences.

All forms of business environment are affected by innovation and change, which is the cornerstone of the modern marketing strategies such as market orientation. Technological changes create opportunities and threats for all organisations (Cravens et al., 1998).

The economic conditions cover the growth rate of the economy, employment levels, consumer income and the inflation rate (Dubihlela, 2010). In this regard, Lamb et al. (2010) suggest that the general economic conditions prevailing in the country should be the starting point of market orientation: assessing opportunities and threats in the marketplace.

\section{Business Performance}

Every form of business organisation (small manufacturer, distributor, financial institution, professional services, support provider, andcountless others) needs to measure how well its business is performing (Appiah-Adu, 1997). Organisations measure their business performance in order to check their position (i.e. compare their position or benchmark or monitor progress), communicate their position (communicate performance internally and with the stakeholders), confirm priorities (manage performance, cost and control, focus investment and actions), and compel progress (as a means of motivation and rewards) (Amaratunga \& Baldry, 2000). Essentially, business performance measurement enables organisations to plan and control their performance and to ensure the sales and marketing initiatives, operating practices, information technology resources, business decision, and employee activities are aligned with strategies to achieve desired business results (Deshpandé \& Farley, 2004).

Kohli and Jaworski (1990) saw business performance as being influenced by four moderators, namely: market turbulence; technological turbulence; competitive intensity; and performance of the economy, which also suggests the possible impact of a national economy. Market and technological turbulence is the rate of change in the composition of customers and their preferences and change in technology that causes an unstable economic climate and continually stirs up the market (Kotler \& Armstrong, 2011). Competitive intensity is a commonly accepted measure of market concentration, indicative of the extent to which organisations put pressure on each other and limit each other's profit potential as they compete for profit and market share (Vieira, 2010).

\section{Market Orientation and Business Performance}

The aim of this section is to examine the possible importance of market orientation and to illustrate its impact on business performance. Market orientation has attracted professional and scholarly interests as a driver of business performance (Walsh \& Lipinski, 2009). According to Vieira (2010), market orientation is an indicator of the extent to which a firm implements its marketing strategy; facilitating the firm's ability to anticipate, react to and capitalise on environmental changes that lead to superior business performance. Roomi et al. (2009) argue that the whole reason for adopting market orientation is that this concept has the ability, at the least, to correlate positively with some measure of business performance. This traditional viewpoint (Chakravarthy, 1986:437) implies that if it is not achieved by the organisation, market orientation has no purpose other than just creating management 
information which is "nice to know". In reviewing the literature on the relationship between market orientation and business performance, it is important to have an understanding of the meaning of business performance.

Numerous researchers (Jaworski \& Kohli, 1996; Kumar, 2002; Narver \& Slater 1990, Pelham \& Wilson, 1994), found unequivocal support for a positive association between market orientation and performance. Hart and Diamantopoulos (1993) identified a positive relationship between market orientation and business performance and recommended the adoption of market orientation as a critical component for business practice. Further studies undertaken by Jaworski and Kohli (2000) report on a direct association between business performance.

Based on the literature review the following hypothesis has been formulated to examine the relationships:

$\mathbf{H}_{1}$ : A positive relationship exists between determinants and enablers of market orientation (DMO) and overall market orientation (MO) of SMEs.

$\mathbf{H}_{2}$ : A negative relationship exists between barriers to market orientation (BMO) and the adoption and implementation of market orientation (MO) by SMEs.

$\mathbf{H}_{3}$ : A positive relationship exists between market orientation (MO) and business performance (BP) (as measured by financial performance, employee organisational commitment, repeat customers).

\section{Methodology}

A quantitative research paradigm was used in the study as the research sought to find relationships between variables through statistical techniques, namely structural modelling analysis.

\section{Sample}

The sample was drawn from registered SMEs from the databases of the Small Enterprise, Emfuleni Municipality in the Vaal Triangle region and the Small Business Directory. Major towns represented in this demarcation included Vereeniging, Sasolburg and Vanderbijlpark. A representative sample was ensured by the inclusion of the three major towns.

\section{Instrumentation and Data Collection}

The study made use of a self-administered questionnaire through face-to-face interviews. The design of the survey instrument was based on the market orientation (MARKOR) instrument which measured SME market orientation (Jaworski \& Kohli, 1996). MARKOR seeks to measure market orientation by collectively analysing perceptions of respondents. Barriers to and determinants and enablers of market orientation were measured on item scales that were developed by Bhuian (1998); Pulendran et al. (2000) and Zebal and Goodwin (2012). Business performance was measured using variables extracted from questionnaires for measuring business performance successfully used by Appiah-Adu (1998), Akimova (2000) and Zebal and Goodwin (2012 in other developing countries. The scales were applied with minor changes to reflect the situation in the South African SME environment. The final sample size of 273 used in the survey was consistent with those used by a number of researchers in the area of the market orientation-business performance relationship. Cox (1979) indicated that personal face-to-face interviews have the potential of yielding a high quantity and quality of data compared with the other survey methods. The method also tends to be flexible although it is expensive. This study adopted this method considering the potential increase in quantity and quality of information that could be obtained (Zebal \& Goodwin, 2012). In addition, the flexibility of the personal interviews justified the increased cost of using it (Cooper \& Schindler, 2006).

Demographic and industry profile data was collected, namely age of owners/managers, their level of education and the length of time the business was in existence. The study employed a 5-point Likert scale, ranging from strongly disagree $=1$ to strongly agree $=5$. The Likert scale was used in sections A (determinants of market orientation, $\mathrm{B}$ (market orientation) and $\mathrm{C}$ (barriers to marketing orientation) $\mathrm{D}$ (business performance) requiring the 
respondents to indicate a degree of agreement or disagreement with each of a series of statements related to the market orientation items (Malhotra, 2010).

Ten research fieldworkers were recruited from a list of registered fourth-year university students pursuing marketing degrees. The ten fieldworkers were briefly trained by the researcher in subject knowledge, interviewing skills, interpersonal skills and professionalism (Kanuk \& Berenson, 1975). Data collection activities took place in the Vaal Triangle region between September and October 2013. The primary researcher undertook fieldwork supervision.

\section{RESULTS AND DISCUSSION}

\section{Sample Composition}

Table 1 report on the age of owners/managers, their level of education and duration of existence of SMEs in the sample. Majority of the respondents were in between 40-49 years. Surprisingly, a large majority were only in possession of a trade certificate. Those with an undergraduate qualification or a degree comprised $29 \%$ of the sample. In terms of the duration of existence of the businesses, majority of SMEs were in existence for more than ten years.

Table 1. Age and level of education of respondents

\begin{tabular}{|c|c|c|c|c|c|c|c|c|}
\hline Age of respondent & Freq & $\%$ & Level of education (respondent) & Freq & $\%$ & Business age & Freq & $\%$ \\
\hline Under 30 years & 40 & 14.7 & No formal education & 4 & 1.64 & $<3$ years & 60 & 22.0 \\
\hline $30-39$ years & 70 & 25.6 & Primary school education & 10 & 3.66 & Between 3-6 years & 54 & 19.8 \\
\hline $40-49$ years & 108 & 39.6 & High school education (Grade 12) & 55 & 20.1 & Between $7-10$ years & 55 & 20.1 \\
\hline $50-59$ years & 47 & 17.2 & Trade certificate & 91 & 33.3 & $>10$ years & 104 & 38.1 \\
\hline \multirow[t]{2}{*}{60 years and above } & 8 & 2.9 & Undergraduate or equivalent degree & 79 & 28.9 & & & \\
\hline & & & Postgraduate & 34 & 12.4 & & & \\
\hline Total & 273 & 100 & Total & 273 & 100 & Total & 273 & 100 \\
\hline
\end{tabular}

\section{Confirmatory Factor Analysis and Statistical Measures of Accuracy Tests}

Since the scale used were adapted from previously scales in predominatley developed countries, the measurement scales were refined. In accordance with the two-step procedure suggested by Anderson and Gerbing (1988), prior to testing the hypotheses, confirmatory factor analysis (CFA) was performed to examine reliability, convergent and discriminant validity of the multi-item construct measures using AMOS 21.0. Robust Maximum Likelihood (RML) was used as it opertes in samples that do not unequivocally overcome the multivariate normailty test (Garson, 2007). These results are reported as a notation in Table 3. Overall acceptable model fit are indicated by Goodness-of-Fit Index (GFI) $\geq 0.80$; Adjusted Goodness-of Fit Index (AGFI) $\geq 0.80$; Root Mean Square Error of Approximation (RMSEA) values $\leq 0.08$; and Comparative Fit Index (CFI) values $\geq 0.90$; and Chi-square degrees of freedom ratio $(\mathrm{CMIN} / \mathrm{DF})$ value $<3$. Recommended statistics for the final overall model assessment show acceptable fit of the measurement model to the data: $\mathrm{CMIN} / \mathrm{DF}=2.85$; GFI $=0.931$; $\mathrm{AGFI}=0.860 ; \mathrm{CFI}=0.919$; $\mathrm{RMSEA}$ $=0.058$.

The Cronbach alpha values for each of the scales making up latent variables (market orientation, determinants/enablers, barriers and business performance) were computed. All the scales used were above the recommended 0.70 threshold for Cronbach alpha (Nunnally, 1978). The minimum value of the item-total correlation among all the constructs was well above the minimum ( $\leqq 0.3)$ recommended by Dunn, Seaker and Waller (1994). Table 2 provides evidence that each of the scales exhibit satisfactory reliability with values ranging from 0.7083 to 0.9023 . 
Table 2. Summary of Cronbach's alpha reliability results

\begin{tabular}{|c|c|c|c|c|c|}
\hline Scale & No. of Items & Cronbach's Alpha & Dimensions/factors & No. of items & $\begin{array}{c}\text { Cronbach's } \\
\text { Alpha }\end{array}$ \\
\hline \multirow{4}{*}{$\begin{array}{c}\text { Market } \\
\text { orientation }\end{array}$} & \multirow{4}{*}{19} & \multirow{4}{*}{0.891} & Responsiveness \& implementation & 9 & 0.8489 \\
\hline & & & Customer focus \& emphasis & 4 & 0.8802 \\
\hline & & & Intelligence dissemination & 3 & 0.8014 \\
\hline & & & Information generation & 3 & 0.7083 \\
\hline \multirow{4}{*}{$\begin{array}{l}\text { Determinants / } \\
\text { enablers of MO }\end{array}$} & \multirow{4}{*}{12} & \multirow{4}{*}{0.767} & Market-based reward system & 4 & 0.8031 \\
\hline & & & Interdepartmental connectedness & 3 & 0.7733 \\
\hline & & & Top management emphasis & 3 & 0.7433 \\
\hline & & & Management risk posture & 2 & 0.7631 \\
\hline \multirow{4}{*}{ Barriers to $\mathrm{MO}$} & \multirow{4}{*}{18} & \multirow{4}{*}{0.804} & Technology turbulence & 6 & 0.8493 \\
\hline & & & Centralisation & 5 & 0.7461 \\
\hline & & & Competitive intensity & 5 & 0.7192 \\
\hline & & & Interdepartmental conflict & 2 & 0.7632 \\
\hline \multirow{3}{*}{$\begin{array}{c}\text { Business } \\
\text { performance }\end{array}$} & \multirow{3}{*}{19} & \multirow{3}{*}{0.904} & Financial performance & 9 & 0.9023 \\
\hline & & & Customer satisfaction \& loyalty & 6 & 0.7643 \\
\hline & & & Organizational commitment & 4 & 0.71631 \\
\hline
\end{tabular}

Further to the measure of Cronbach alpha, the composite reliability (CR) coefficient was also computed to establish the reliabilities of the measurement constructs. The CR coefficient does not assume that all indicators are equally weighted (Chen, 1998). Interpreted like a Cronbach's alpha, the CR measure of 0.70 is a threshold for "modest" composite reliability ( $\mathrm{Li}$ et al., 2008). The CR results shown in Table 3 are used to test the internal consistency of the measurement model.

Table 3. Accuracy analysis statistics

\begin{tabular}{|c|c|c|c|c|c|c|c|c|c|}
\hline \multirow{2}{*}{\multicolumn{2}{|c|}{ Research Constructs }} & \multicolumn{2}{|c|}{ Descriptive Statistics* } & \multicolumn{2}{|c|}{ Cronbach's Test } & \multirow{2}{*}{ C.R. } & \multirow{2}{*}{ AVE } & \multirow{2}{*}{$\begin{array}{c}\text { Factor } \\
\text { Loading }\end{array}$} & \multirow{2}{*}{$\begin{array}{l}\text { Highest } \\
\text { S.V. }\end{array}$} \\
\hline & & Mean & SD & Item-total & $\alpha$ Value & & & & \\
\hline $\begin{array}{l}\text { Business } \\
\text { Performance } \\
\text { (BP) }\end{array}$ & $\begin{array}{l}\mathrm{I}_{\mathrm{BP}-1} \\
\mathrm{I}_{\mathrm{BP}-2} \\
\mathrm{I}_{\mathrm{BP}-3} \\
\mathrm{I}_{\mathrm{BP}-4} \\
\mathrm{I}_{\mathrm{BP}-5} \\
\mathrm{I}_{\mathrm{BP}-6} \\
\mathrm{I}_{\mathrm{BP}-7} \\
\mathrm{I}_{\mathrm{BP}-8} \\
\mathrm{I}_{\mathrm{BP}-9} \\
\mathrm{I}_{\mathrm{BP}-10} \\
\mathrm{I}_{\mathrm{BP}-11} \\
\mathrm{I}_{\mathrm{BP}-12} \\
\mathrm{I}_{\mathrm{BP}-13} \\
\mathrm{I}_{\mathrm{BP}-14} \\
\mathrm{I}_{\mathrm{BP}-15} \\
\mathrm{I}_{\mathrm{BP}-16}\end{array}$ & 3.830 & 0.690 & $\begin{array}{l}0.587 \\
0.651 \\
0.721 \\
0.623 \\
0.612 \\
0.707 \\
0.649 \\
0.646 \\
0.506 \\
0.525 \\
0.709 \\
0.542 \\
0.633 \\
0.631 \\
0.593 \\
0.588 \\
\end{array}$ & 0.915 & 0.947 & 0.437 & $\begin{array}{l}0.782 \\
0.764 \\
0.687 \\
0.695 \\
0.675 \\
0.680 \\
0.698 \\
0.624 \\
0.719 \\
0.644 \\
0.623 \\
0.539 \\
0.543 \\
0.503 \\
0.500 \\
0.500 \\
\end{array}$ & 0.262 \\
\hline $\begin{array}{l}\text { Barriers to } \mathrm{MO} \\
(\mathrm{BMO})\end{array}$ & $\begin{array}{l}\mathrm{I}_{\text {BMO-1 }} \\
\mathrm{I}_{\text {BMO-2 }} \\
\mathrm{I}_{\text {BMO-3 }} \\
\mathrm{I}_{\text {BMO-4 }} \\
\mathrm{I}_{\text {BMO-5 }} \\
\mathrm{I}_{\text {BMO-6 }} \\
\mathrm{I}_{\text {BMO-7 }} \\
\mathrm{I}_{\text {BMO-8 }}\end{array}$ & 3.716 & 0.916 & $\begin{array}{l}0.570 \\
0.578 \\
0.633 \\
0.611 \\
0.532 \\
0.705 \\
0.642 \\
0.590 \\
\end{array}$ & 0.814 & 0.838 & 0.400 & $\begin{array}{l}0.520 \\
0.761 \\
0.803 \\
0.579 \\
0.651 \\
0.671 \\
0.500 \\
0.500 \\
\end{array}$ & 0.372 \\
\hline $\begin{array}{l}\text { Determinants of } \\
\text { MO (DMO) }\end{array}$ & $\begin{array}{l}\mathrm{I}_{\text {DMO-1 }} \\
\mathrm{I}_{\text {DMO-2 }} \\
\mathrm{I}_{\text {DMO-3 }} \\
\end{array}$ & 3.973 & 0.803 & $\begin{array}{l}0.543 \\
0.594 \\
0.571 \\
\end{array}$ & 0.743 & 0.728 & 0.497 & $\begin{array}{l}0.996 \\
0.500 \\
0.500 \\
\end{array}$ & 0.405 \\
\hline $\begin{array}{l}\text { Market } \\
\text { Orientation } \\
(\mathrm{MO})\end{array}$ & $\begin{array}{l}\mathrm{I}_{\mathrm{MO}-1} \\
\mathrm{I}_{\mathrm{MO}-2} \\
\mathrm{I}_{\mathrm{MO}-3}\end{array}$ & 3.777 & 0.984 & $\begin{array}{l}0.833 \\
0.807 \\
0.580\end{array}$ & 0.834 & 0.755 & 0.734 & $\begin{array}{l}0.579 \\
0.997 \\
0.935\end{array}$ & 0.315 \\
\hline
\end{tabular}

Note: $\mathrm{BP}=$ Business Performance; $\mathrm{BMO}=$ Barriers to Market Orientation; DMO $=$ Determinants of Market Orientation; MO $=$ Market Orientation; AVE: Average Variance Extracted; * Scores: 1 - Strongly Disagree; 5 - Strongly Agree C.R.: Composite Reliability; ${ }^{a}$ significance level $p<0.05 ;{ }^{\mathrm{b}}$ significance level $p<0.01 ;{ }^{\mathrm{c}}$ significance level $p<0.001$. Measurement CFA model fits: $\chi^{2} /(\mathrm{df})=2.85 ;$ GFI $=0.931 ;$ AGFI $=0.86$; $\mathrm{CFI}=0.919 ; \mathrm{NNFI}=0.921 ; \mathrm{RMSEA}=0.058$ 
The higher level of CR coefficient demonstrated higher reliability of the scale. Moreover, higher inter-item correlations revealed statistical agreement among the measured items. The composite reliability (CR) values ranged from 0.728 to 0.947 . The indicators for both the Cronbach's test ( $\alpha$ value) and the CR indices were all high (see Table 3). The results indicate all the $\mathrm{CR}$ values exceeding the threshold of 0.70 recommended in the literature (Chen, 1998; Nunnally, 1978) and therefore, confirm that the measures used in this study are reliable.

The average variance extracted (AVE) is also another method of estalishing scale reliability.The average variance extracted (AVE) estimates (see Table 3) reflected that the overall amount of variance in the indicators were accounted for by the latent construct (Neuman, 2006). Higher values for the AVE (greater than 0.40) reveal that the indicators well represented the latent construct. Overall, all average variance explained (AVE) values were above 0.4 , thus acceptable according to the literature ( $\mathrm{Li}$ et al., 2008). These results provided evidence for acceptable levels of research scale reliability.

Convergent validity was assessed by checking if individual item loadings for each corresponding research construct was above the recommended value of 0.50 (Aldalaigan \& Buttle, 2002). Table 3 show that the factor loadings ranged from 0.500 to 0.997 . Therefore, all the items finally used had loadings of more than the recommended 0.500 , indicating acceptable individual item convergent validity as more than 50 percent of each item's variance was shared with its respective construct (Dunn et al., 1994).

Discriminant validity of the research constructs was ascertained through correlations in order to establish whether the correlations among latent constructs were less than 1.0 (Nunnally, 1978). As indicated in Table 4 the inter-correlation values for all paired latent variables are less than 1 , indicating the existence of discriminant validity.

Table 4. Correlations between constructs

\begin{tabular}{|c|c|c|c|c|}
\hline \multirow{2}{*}{ Research Construct } & \multicolumn{4}{|c|}{ Construct Correlation } \\
\hline & DMO & BMO & MO & BP \\
\hline Determinants of Market Orientation (DMO) & 1.000 & & & \\
\hline Barriers of Market Orientation (BMO) & 0.606 & 1.000 & & \\
\hline Market Orientation (MO) & 0.427 & 0.559 & 1.000 & \\
\hline Business Performance (BP) & 0.712 & 0.483 & 0.394 & 1.000 \\
\hline
\end{tabular}

Discriminant validity was established by confirming that the AVE values were greater than the highest shared variance values (Nunnally, 1978). Table 3 show that all the average value extracted (AVE) are above the shared variance values (SV) for all the research constructs, therefore further confirming the existence of discriminant validity.

\section{Conceptual Model Fit Assessments}

According to Anderson and Gerbing (1988), prior to testing the hypotheses, confirmatory factor analysis (CFA) is performed to confirm accuracy of the multiple-item constructs measures. In this study AMOS 21.0 was used. A confirmatory measurement or confirmatory factor analysis model, specifies the relations of the observed measures to their posited underlying constructs, with the constructs allowed to inter-correlate freely (Chen, 1998). Initial specification search led to the deletion of the items that were less than the recommended 0.5. This was done to provide for an acceptable fit and the resultant scale accuracy.

Acceptable model fit was indicated by chi-square value over degree of freedom $\left(\chi^{2} / \mathrm{df}\right)$ of value between 1 and 3, the values of Goodness-of-Fit Index (GFI), Comparative Fit Index (CFI), Incremental Fit Index (IFI), and Tucker-Lewis Index (TLI) equal to or greater than 0.90; and the Root Mean Square Error of Approximation (RMSEA) value equal to or less than 0.08 .

Figure 1 outlines the model fit indices for the structural model. The overall observed data fits the model reasonably well (CFA model fit results) as it is within the recommended statistics for the final overall-model assessment. All the indicators showed acceptable fit of the measurement model for the dataset $\left(\chi^{2} / \mathrm{df}=2.620\right.$; $\mathrm{GFI}=0.901 ; \mathrm{AGFI}=0.86 ; \mathrm{CFI}=0.900 ; \mathrm{NNFI}=0.911$; RMSEA $=0.060$ ). These results are within acceptable levels, suggesting achieved thresholds (Browne \& Cudeck, 1993; Marsh et al., 2007). This suggests that the model 
converged well and could be a plausible representation of underlying empirical data structures collected in a South African setting.

Since an acceptable CFA measurement model fit was obtained, the study proceeded to test the hypothesis.

\section{Structural Equation Modeling (SEM) Analysis And Hypotheses Testing}

In order to test the direct and indirect effects of barriers to market orientation and the determinants of market orientation on market orientation, as well as the direct and indirect effects of market orientation on business performance, a structural equation modeling (SEM) was undertaken using AMOS version 21.0 statistical software programme.

The model hypothesized and reflected in this section of the analysis posits four components (barriers to market orientation (BMO), determinants of market orientation (DMO), market orientation (MO) and business performance (BP). The path diagram for the CFA is reflected in Figure 1 as exogenous constructs, with the estimated parameter values added.

The corresponding path coefficients of the research hypotheses posited observable existence of positive relationships between the determinants of market orientation (DMO) and market orientation (MO), market orientation and business performance (BP), and a negative relationship between the barriers to market orientation (BMO) and market orientation. Table 5 presents these results. 
Figure 1. Structural model of the relationship between constructs

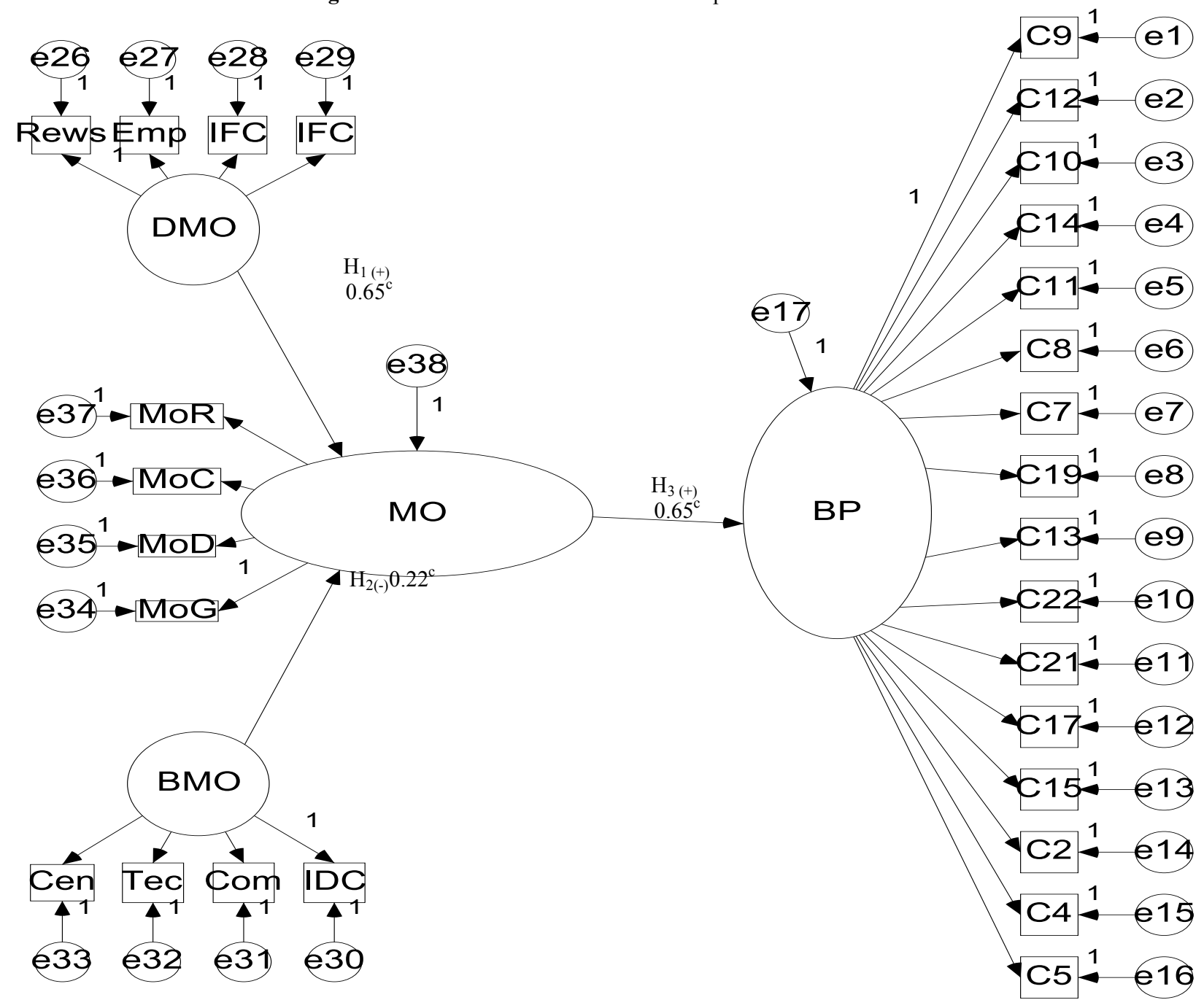

\begin{tabular}{|l|}
\hline Note: Research structure model fits: \\
\hline$\chi^{2} / \mathrm{df}=2.620 ; \mathrm{GFI}=0.901 ; \mathrm{AGFI}=0.86 ; \mathrm{CFI}=0.900 ;$ \\
$\mathrm{NNFI}=0.911 ; \mathrm{RMSEA}=0.060$ \\
significance level $<0.05 ;$ \\
b significance level $<0.01 ;$ \\
c significance level $<0.001$ \\
DMO (Determinants of Market Orientation), BMO \\
(Barriers to Market Orientation), MO (Market \\
Orientation), BP (Business Performance) \\
\hline
\end{tabular}

Results in Table 5 show that proposed hypotheses $\left(\mathrm{H}_{1}\right.$ to $\left.\mathrm{H}_{3}\right)$ were all supported. Individual hypothesis path coefficients of the modularised relationship outcomes were $0.810(\mathrm{p}<0.001),-0.220(\mathrm{p}<0.05)$, and $0.650(\mathrm{p}<0.001)$ respectively. 
Table 5. Results of hypotheses

\begin{tabular}{lccc}
\hline \multicolumn{1}{c}{ Hypothesis } & Hypothesis & Path Coefficient & Hypothesis Decision \\
\hline $\begin{array}{l}\text { Determinants of Market Orientation } \\
\rightarrow \text { Market Orientation }\end{array}$ & $\mathrm{H} 1$ & $0.810^{* * *}$ & Supported \\
$\begin{array}{l}\text { Barriers to Market Orientation } \\
\rightarrow \text { Market Orientation }\end{array}$ & $\mathrm{H} 2$ & $-0.220^{*}$ & Supported \\
$\begin{array}{l}\text { Market Orientation } \\
\rightarrow \text { Business Performance }\end{array}$ & $\mathrm{H} 3$ & $0.650^{* * *}$ & Supported \\
\hline $\begin{array}{l}\text { Structural model fits: } \chi^{2} / \mathrm{df}=2.620 ; \mathrm{GFI}=0.901 ; \mathrm{AGFI}=0.86 ; \mathrm{CFI}=0.900 ; \mathrm{NNFI}=0.911 ; \mathrm{RMSEA}=0.060 \\
* \text { significance level }<0.05 ; * * \text { significance level }<0.01 ; * * * \text { significance level }<0.001\end{array}$
\end{tabular}

The empirical model is depicted in Figure 1 suggesting DMO (determinants of market orientation) have a positive impact $\left(\mathrm{H}_{1}+\right)$ on MO (market orientation); BMO (barriers to market orientation) have a negative $\left(\mathrm{H}_{2}-\right.$ ) impact on $\mathrm{MO}$; and that $\mathrm{MO}$ has a positive $\left(\mathrm{H}_{3}+\right)$ impact on $\mathrm{BP}$ (business performance).

The results of the relationships lend substantial support to the previous findings of Jaworski and Kohi (1996), Slater and Narver (1994) and Pelham (2000). These studies confirmed that market orientation has a significant positive effect on performance. Harris (2002) and Li et al. (2008) identified the existence of barriers to market orientation and determinants of market orientation. Although Zebal and Goodwin (2012) groups them together as antecedents of market orientation, their relationship with market orientation is identified. Deshpande and Farley (2004) state that market orientation provides a unifying focus for the efforts and projects of individuals and departments within an organisation in order to create superior value for customers, leading to superior performance. The effect of the determinants/enablers of market orientation and barriers to market orientation are also reflected in the model. In other words, market-oriented SMEs are more likely to succeed if they understand the underlying factors that impact their market-oriented strategies. The motivation is to enhance the value of the SMEs market oriented offerings to customers (determinants/enablers) and to lower the negative impact of the barriers.

\section{LIMITATIONS}

Although this study makes significant contributions to both academia and practice, there are some limitations, which open up avenues for further research. The sample was limited to SME owners/managers in the vaal Triangle, one region in South Africa. Hence the results in terms of generalisations to a wider population must be treated with acution. Further, data was analysed from 273 owner/managers were of SMEs. A large sample size in the future may yield more interesting results. Extending the research to other regions in South Africa and testing the conceptual model might be a valuable future research direction.

\section{CONCLUSION}

The study identified the conditions that foster or discourage market orientation, and the contribution that market orientation can have on business performance for SMEs. The SMEs in South Africa can achieve market orientation with the aid of the market orientation-business performance (MO-BP) model without much discord, as essential elements in the model have been incorporated on the basis of the findings of this study. SMEs can select the determinants of market orientation and overcome the barriers that discourage market orientation. Further, the study confirms that superior business performance is influenced by the level of market orientation of an organisation. Managers/owners of the SMEs in South Africa must be motivated to commit resources towards being market oriented. In so doing, SMEs will be able to project the cost-benefit ratio by looking at the cost of the resources of becoming market oriented versus the benefits derived from adopting market-oriented behaviour.

\section{AUTHOR INFORMATION}

Prof J. Dubihlela, PhD., is a former banker-turned-academic. He is currently associate professor in the Faculty of Business and Economic Sciences at the Nelson Mandela Metropolitan University, with keen interest on green and small business issues.

Prof M. Dhurup is the executive dean of the Faculty of Management Sciences at Vaal University of Technology, South Africa. Dr Job Dubihlela is senior lecturer cum researcher in the same faculty at Vaal University of Technology. 


\section{REFERENCES}

Akimova, I. (2000). Development of market orientation and competitiveness of Ukrainian firms. European Journal of Marketing, 34(9):1128-1148.

Aldalaigan, A. H. \& Buttle, F. A. (2002). System and Transactional Service Quality scale (SYSTRA-SQ): A new measure of bank service quality. Industrial Journal of Service Industry Management, 13(3):362-381.

Amaratunga, D. \& Baldry, D. (2000). Theory building in facilities management research: case study methodology. Proceedings of the Bizarre Fruit Postgraduate Conference. Salford: University of Salford.

Anderson, J. C. \& Gerbing, D. W. (1988). Structural Equation Modeling in Practice: A Review and Recommended TwoStep Approach, Psychological Bulletin, 103 (May), 411-423.

Appiah-Adu, K. (1997). Market orientation and performance: do the findings established in large firms hold in the small business sector? Journal of Euro-Marketing, 6 (3):1-26.

Bhuian, S. N. (1998). An empirical examination of market orientation in Saudi Arabian manufacturing companies. Journal of Business Research, 43:13-25.

Blewett, S. (1999). Practical marketing and sales for South African business. Kenwyn: Juta.

Browne, M. W., \& Cudeck, R. (1993). Alternative ways of assessing model fit. In K. A. Bollen \& J. S. Long (Eds.), Testing structural equation models(pp. 136-162). Newbury Park, CA: Sage.

Chakravarthy, B.S. (1986). Measuring strategic performance. Strategic Management Journal, 7:437-458.

Chen, C. (1998). Market Orientation of small and medium sized firms in Taiwan. Journal of Small Business Management, 36 (3): $79-85$.

Cooper, P.S. \& Schindler, D.R. (2003). Business research methods. 8th edition. New York: McGraw-Hill.

Cox, E. P. (1979). Marketing research. 2nd edition. Fort Worth: Dryden Press.

Cravens, D., Greenley, G., Piercy, N.F. \& Slater, S.F. (1998). Mapping the path to market leadership. Marketing Management, 7(3): 29-33.

Day, G.S. (2000). The market driven organisation. Direct Marketing, 62(10):20-24.

Deshpandé, R. \& Farley, J. U. (2004). Organizational culture, market orientation, innovativeness, and firm performance: an international research odyssey. International Journal of Research in Marketing, 21(1):3-22.

Dubihlela, D. (2010). Socio-economic challenges and the survival mechanisms for the female-headed households in the Bophelong Township. Vanderbijlpark: North-West University (M-Com dissertation).

Dunn, S. C., Seaker, R. F. \& Waller, M. A. (1994). Latent variables in business logistics research: Scale development and validation. Journal of Business Logistics, 15 (2): 145-172.

Dursun-Kilic, T. (2006). An empirical investigation of the link between market orientation and new product performance: The mediating effects of organizational capabilities. Norfolk, Virginia: Old Dominion University ( $\mathrm{PhD}$ thesis).

Edigheji, O.E. (2010). Constructing a democratic developmental State in South Africa: Potentials and Challenges. Cape Town: Human Science Research Council Press.

Flavián, , C., Guinaíu, M. \& Gurrea, R. (2006). The role played by perceived usability, satisfaction and consumer trust on website loyalty. Information \& Management, 43, 1-14.

Garver, M. S. \& Gagnon, G. (2002). Seven keys to improving customer satisfaction programs. Business Horizons, 16(2):35-42.

Garson, G.D. (2007). Reliability analysis. In Statsnotes. Topics in multivariate analysis. [Online]. Available at: $<$ www2.chase.ncsu.edu/garson/p.765/reliable.htm>. (Accessed: 2 January, 2014).

Guo C. (2003). Market Orientation and Business Performance: A framework for service organisation. European Journal of marketing, 36(9/10):1154-1163.

Hart, S. \& Diamantopoulos, A. (1993). Linking market orientation and company performance: Preliminary work on Kohli and Jaworski's framework. Journal of Strategic Marketing, 1(2): 93-122.

Harris L.C. (2002). Sabotaging market-oriented culture change: an exploration of resistance justification and approaches. Journal of Marketing, 34(516): 598-624.

Hill, J. \& Wright, L. T. (2001). A qualitative research agenda for small to medium-sized enterprises. Marketing Intelligence \& Planning, 19(6):432-443.

Jaworski, B.J. \& Kohli, A.K. (1996). Market orientation: review, refinement and roadmap. Journal of Market-focused Management, (1):119-135.

Jaworski, B.J. \& Kohli, A.K. (2000). Market-driven versus driving markets. Journal of the Academy of Marketing Science, 28 (1):45-54.

Kanuk, L. \& Berenson, C. (1975). Mail surveys and response rates: a literature review. Journal of Marketing Research, (4): 440-53.

Kohli, A.K. \& Jaworski, B.J. (1990). Market orientation: The construct, research propositions, and managerial 
implications. Journal of Marketing, 54 (1):1-18.

Kotler, P. \& Armstrong, G. (2011). Principles of Marketing. $14^{\text {th }}$ edition. Boston: Prentice-Hall.

Kumar, K. (2002). Market orientation, organizational competencies and performance: An empirical investigation of a path-analytic model. Journal of American Academy of Business, 1(2): 371-376.

Lamb, C. W., Hair, J. F., McDaniel, C., Boshoff, C. \& Terblanche, N.S. (2010). Marketing - South African 4th edition. Cape Town: Oxford University Press Southern Africa.

Levitt, T. (1980). Marketing success through differentiation of anything. Harvard Business Review, 58(1): 83-91.

Li, Y., Zhao, Y., Tan, J. \& Liu, Y. (2008). Moderating effects of entrepreneurial orientation on market orientation performance linkage: Evidence from Chinese small firms. Journal of Small Business Management. 46:113-133.

Maholtra, N. K. (2010). Marketing research: An applied orientation.6th edition. Eaglewood Cliffs: Prentice- Hall.

Marsh, H.W, Wen, Z., Hau, K-T, Little, T.D, Bovaird, J,A, \& Widaman, K.F. (2007). Unconstrained structural equation models of latent interactions: Contrasting residual- and mean-centered approaches. Structural Equation Modeling, 14, 570-580.

Maydeu-Olivares, A. \& Lado, N. (2003). Market orientation and business economic performance: A mediational model. International Journal of Service Industry Management, 14(3):284-309.

Narver, J.C. \& Slater, S.F. (1990). The effect of a market orientation on business profitability. Journal of Marketing, 54, October, 20-35.

Narver, J.C., Slater, S.F. \& Tietje, B. (1998). Creating a market orientation. Journal of Market- Focused Management, 2 (3): 241-256.

Neuman, L. W. (2006). Social research methods: Qualitative and quantitative approaches. $6^{\text {th }}$ edition. Boston:Pearson International Education.

Ntsika Enterprise Promotion Agency, South Africa. (2009). http:1/www.ntsika.org.za Date of access: 19 Jan. 2014.

Nunnally, J.C. (1978). Psychometric theory. New York: McGraw-Hill.

Oczkowski, E. \& Farrell, M. (1998). An Examination of the Form of Market Orientation in Australian Companies. Australasian Marketing Journal, 6:3-12.

Pelham, A. M. \& Wilson. D. T. (1996). A longitudinal study of the impact of market structure, firm structure, strategy and market orientation culture on dimensions of small-firm performance. Journal of the Academy of Marketing Science, 24(1):27-43.

Piercy, N. (1995). Customer satisfaction and the internal Market: Marketing our customers to our employees. Journal of Marketing Practice and Applied Marketing Science, 1 (1):22-44.

Pulendran, S., Speed, R. \& Widing, R.E. (2000). Antecedents and consequences of market orietation in Australia. Australian Journal of Management, 25(2):119-143.

Republic of South Africa. (2004). National Small Business Act, No. 102 of 2004. Cape Town: Government Gazette 27101, 15 December.

Roomi, M. A., Harrison, P. \& Beaumont-Kerridge, J. (2009). Women-owned small and medium enterprises in England: Analysis of factors influencing the growth process. Journal of Small Business and Enterprise Development, 16(2): 270-288.

Ruekert, R.W. (1992). Developing a market orientation: an organizational strategy perspective. International Journal of Research in Marketing, 9, 225-45.

Statistics South Africa. (2005). Gross Domestic Product: second quarter 2005. hnp:/lwww.statssa.gov.zalPublicationsiP412ndQuarter2004.pdf. Date of access: 7 Aug. 2013.

Sin LJM, Tse ACB, Yau OHM, Chow R \& Lee JSY. (2003). Market Orientation and Business Performance: A Comparative Study of Firms in Main land China and Hong Kong. European Journal of Marketing, 37(5/6):910936.

Vieira V.A. (2010). Antecedents and consequences of market orientation: a Brazilian meta-analysis and an international mega-analysis. Brazilian Administration Review, Curitiba, 7:44-58.

Walsh, F.M. \& Lipinski, J. (2009). The role of the marketing function in small and medium sized enterprises. Journal of Small Business and Enterprise Development. 16: 569-585.

White, D.W. \& Simas, C.F. (2008). An empirical investigation of the link between market orientation and church performance. International Journal of Non-profit and Voluntary Sector Marketing.13:153-165.

Zebal, M.A. \& Goodwin, D.R. (2012). Market orientation and performance in private universities. Marketing Intelligence and Planning, 30(3): 339-357. 